\title{
A SWOT Analysis of Application-Oriented Undergraduate Colleges Transfer into Vocational Education Universities-An Example from China
}

\author{
Shi Lizhen ${ }^{1,2}$ \\ 1.Inner Mongolia Honder College of Arts and Sciences, Hohhot, Inner Mongolia, 010070 \\ 2.International Education of Philippine Christian University, Philippine, Manila, 999005 \\ * E-mail of the corresponding author: 979235337@qq.com
}

\begin{abstract}
In the present ear, vocational education's availability and quality are crucial. Recently, Theoretically, and practically, it is necessary to develop a sustainable and distinctive talent training program as the youth are unemployed. Therefore, this article analyzes the strength, weaknesses, opportunities, and threats for undergraduate, vocational colleges to transfer into vocational educational universities. Based on the current educational policy, this study used a SWOT analysis approach to the situation of local private colleges in Inner Mongolia, China. Finally, this study proposes suggestions and recommendations based on the conclusion for local private vocational colleges and points out some advantages of vocational undergraduate education. Furthermore, this study reveals that it is much more beneficial and optimistic for private vocational colleges to carry out vocational education in the present era.
\end{abstract}

Keywords: private university, vocational education, SWOT analysis, undergraduate

DOI: $10.7176 / \mathrm{JEP} / 13-6-01$

Publication date: February $28^{\text {th }} 2022$

\section{Introduction}

In the present era, applied skills learned by undergraduate technical talents in vocational colleges are necessary to meet social development needs [1]. The ultimate purpose of technical education is to bring up applied skills. It is an important carrier to produce the craftsman spirit [2]. Vocational, undergraduate education should also cover the training of senior skilled labor and technicians. Based on the training of students enrolled in technical vocational education institutes, these training covers the necessary basic skills to bring up the professional talents with highlevel demand for theoretical knowledge in some high-tech industries. The main difference between vocational, undergraduate education and technology application undergraduate education is that technology application usually refers to academic or engineering education with application properties. The result of internal differentiation in academic or engineering education. The nature of this education is often theoretical. The logical starting point of talent training is theoretical knowledge. Just in the talent training mode is a more prominent application, practical, emphasizing theory in practice [3].

Recently, the General Office of the CPC Central Committee and the State Council issued the policy to promote the High-quality development of Modern Vocational Education. By 2025, this vocational education institute will be more distinctive in the coming years. Furthermore, it is expected that the modern vocational education system will be completed at the end of 2025 in China. Consequently, the construction of a professional society will be promoted in an all-around way [4]. The pattern of running vocational institutes has been much more optimized, the conditions and the policies have been greatly improved. The enrollment of vocational undergraduates for vocational education has been no less than $10 \%$ of higher vocational education, the attractiveness and quality of vocational education have been significantly improved. By 2035 , vocational education levels will be at the top of the world education system, which will complete a professional society. In addition, the social status of technical and skilled personnel has been significantly improved. The supply of vocational education has increased and matched the economic and social development needs. All these factors will play a prominent role in building a modern socialist country. The policies issued by the government and the market demand of technical undergraduates indicates the importance of vocational education institutes, pointing out that the vocational education system has a broad future and great potential in the new journey of comprehensively building a modern socialist country.

\section{Path and present situation of vocational institutes}

2.1 Path to develop undergraduate-level vocational college

Policies issued by the educational authorities local and central government pointed out that the national policy for the development of vocational education at the undergraduate level is becoming more apparent and firmer. The vocational undergraduate colleges have been developed actively and steadily. According to the government statical record, currently, there are 32 undergraduate, vocational colleges in China [4]. In point of view, the impact and 
demand of vocational education colleges are increasing daily. Therefore, the paths, policies, and practical choices for colleges to change their educational system into the vocational education system are as follows:

In the coming years, the regular undergraduate universities will convert their educational majors into application-oriented undergraduate universities. From the perspective of the transformation path of ordinary undergraduate universities to apply for applied-oriented universities, most of them are independent and private undergraduate colleges [4].

(2) According to the government policy, private higher vocational colleges shall be upgraded to vocational schools at the undergraduate level. From the perspective of the upgrading path of private higher vocational colleges, higher vocational colleges are independent of upgrading their undergraduate-level vocational colleges, and personal higher vocational colleges account for the vast majority.

(3) Independent and higher vocational colleges can be merged with vocational and technical colleges. In May 2020, the Ministry of Education issued the Implementation Plan on Accelerating the Transfer of Independent Colleges, which proposed that "independent colleges can explore the integration of educational resources of higher vocational colleges in the province." The merger path of independent colleges and higher vocational colleges brings new vitality and hope for promoting higher vocational colleges.[5]

(4) "Double Higher High Plan."

According to the "Double Higher High plan", currently working higher vocational schools will be upgraded into vocational schools to enroll students at the undergraduate level. According to Vice-Premier Sun Chunlan, to develop vocational education at the undergraduate level, institutes should follow the principle of "three and three unchanged" rule". The "three and three unchanged" rule explains, to adhere the high standards, high starting point, and high quality, comply with the attribute orientation, training mode, and the name of characteristic schools unchanged [6]. The "double higher high plan" higher vocational schools to hold undergraduate, vocational education is entirely in line with the principle of "three and three unchanged." Figure 1 explains the starting point is based on high standards, high starting point, high quality of the modern vocational education with Chinese characteristics.

\subsection{The basic situation of applied undergraduate courses in the autonomous region}

In 2016, local education authorities issued the Notice on Announcing the List of Pilot Schools for the Transformation and Development of Ordinary Undergraduate Universities, confirming that 5 undergraduate universities were overall transformed into application-oriented pilot universities, and some majors (clusters) of 4 ordinary undergraduate universities were transformed into application-oriented pilot projects. It is a significant decision and deployment made by the State Council to guide some

\subsection{Current situation of application-oriented undergraduate courses}

In 2016, local education authorities issued the Notice on Announcing the List of Pilot Schools for the Transformation and Development of Ordinary Undergraduate Universities, confirming that 5 undergraduate universities were overall transformed into application-oriented pilot universities, and some majors (clusters) of 4 ordinary undergraduate universities were transformed into application-oriented pilot projects. It is a significant decision and deployment made by the State Council to guide some undergraduate universities to change applications. It is also an important measure to further promote the structural adjustment of higher education, accelerate the training of applied technical personnel, improve the social serviceability of colleges and universities, and promote the character development of colleges and universities.

Figure 1 - 1 Several major sources for undergraduate, vocational universities

Changes in the number of undergraduate vocational universities

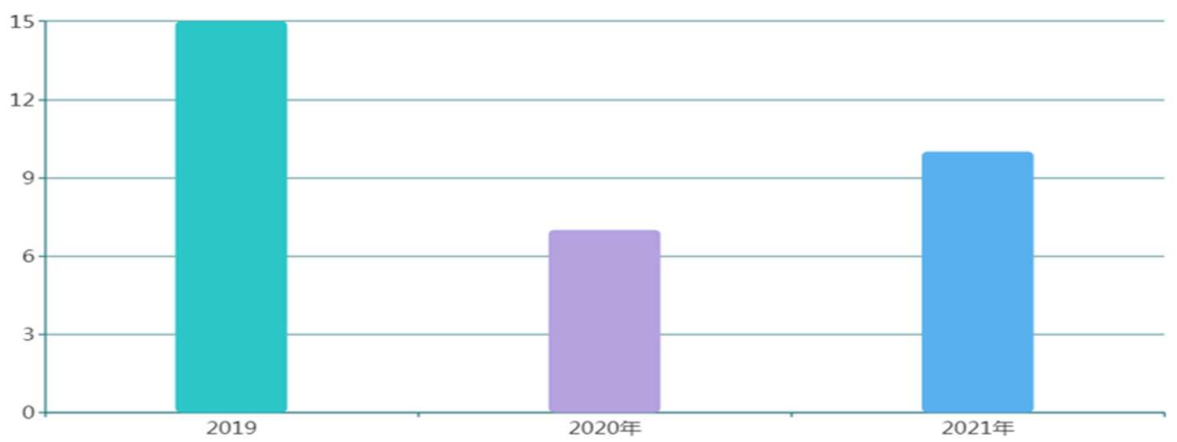

Figure $1-2$ Changes in the number of undergraduate, vocational universities 


\section{Provincial Distribution of Undergraduate Vocational Universities}

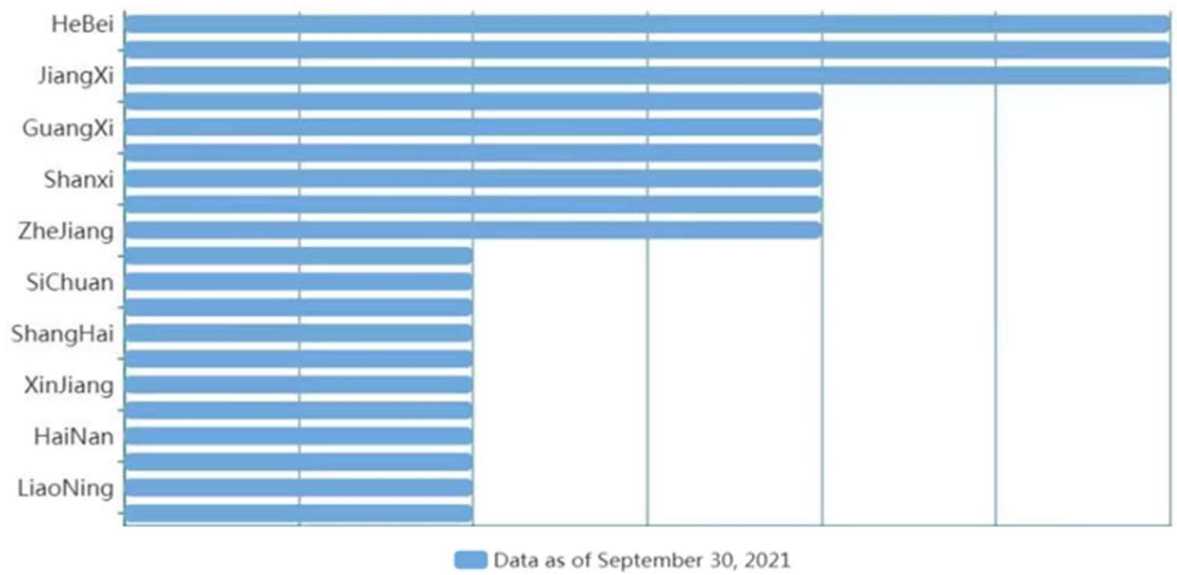

Figure 1-3 Distribution of the provinces (20 provinces) of undergraduate, vocational universities

3 Available majors in higher vocational education and the basic situation of the major setting of Undergraduate Colleges

3.1 Setting up of majors in higher vocational education

On March 17, 2021, the Ministry of Education on the vocational education professional directory (2021) notice $(2,2021)$, according to the "difference" national economic and social development and 2035 vision for vocational education, in scientific analysis industry, occupation, post, professional relationship, major unified categories, experienced, professional classification, set 19 majors, 97 majors, 1349 majors, including 358 secondary vocational specialties, 744,247 undergraduate majors respectively [12][13].

\subsection{Setting up of general undergraduate majors in a local university}

Currently, institutes offer six majors as literature, management, education, engineering, economics, and artscience, with 26 general undergraduate majors and five specialized majors. In addition, the education ministry announces to start of 16 new majors. In the next step, the government will promote the trend of high-quality development of vocational education, encourage application-oriented undergraduate colleges to carry out vocational, undergraduate education policies, and follow the principle of application-oriented undergraduate colleges and vocational colleges to attract more middle and higher vocational colleges to apply for the regulation of roughly matching these majors. At the same time, continue to do an excellent job in the extraordinary enrollment work and actively use it for professional undergraduate majors.

\section{Enrollment policies and situation of modern vocational education}

4.1 Establishment of examination and enrollment system for vocational education

The government will standardize and implement the matching entrance examination system for secondary vocational schools and separate enrollment and examination systems for higher vocational colleges to further improve the evaluation method of the "cultural quality + vocational skills" examination. [14]. Furthermore, the government will adhere to the primary position of secondary vocational education, will actively explore the mode of running comprehensive senior high schools, and fully implement the "vocational integration." In addition, the government will develop higher vocational education at a high level to improve the system for training high-level application-oriented personnel.

\subsection{Building an "overpass" for vocational, undergraduate education}

The government is considering building an overpass for undergraduate education to strengthen the modern vocational education talent training system. The central government will fully design a talent training system for vocational education to promote the mutual selection and recognition of credits between secondary vocational schools, ordinary senior high schools, higher vocational schools, and application-oriented universities. Government decide to implement the "3 +2", "3 +2" $3+2$ "for higher vocational colleges, and" $3+2+2$ " for secondary and vocational colleges [15]. The Opinions require that the enrollment scale of vocational, undergraduate education should not be less than $10 \%$ of the higher vocational education enrollment scale, which encourage application-oriented undergraduate schools to carry out vocational, undergraduate education, and guide application-oriented undergraduate schools and vocational, undergraduate schools to attract higher vocational 
graduates following the principle of roughly matching their majors. To Actively strive for the enrollment plan, improve the application of national brand majors, appropriately increase the professional undergraduate application, expand the basis of students, attract high-quality students, and improve the comprehensive competitiveness of the Undergraduate Colleges [16].

\subsection{Undergraduate, vocational courses and undergraduate employment}

In the present era, undergraduates, vocational courses, and undergraduate employment prospectus are broadening, and social recognition has been significantly improved. According to the Implementation Plan for National Vocational Education Reform issued by the State Council, "vocational education and general education are two different types of education with equally important status. "First, undergraduate graduates have much higher demand in the employment market, integrate industry and education, school-enterprise cooperation, which will promote employment for vocational undergraduates [17]. At the same time, professional undergraduate graduates will receive better practical knowledge, real-time practice, training, and firm competitiveness in the talent market. Second, enterprises highly match the needs of talents. To significantly improve social recognition, vocational institutes must consider the required talent in the market and promote these skills.

\subsection{Vocational, undergraduate education enrollment}

Currently, the vocational undergraduate education enrollment is unbalanced in various regions. In the past three years, the state-approved vocational undergraduate education enrollment situation in multiple areas has been unstable [18]. For example, in 2019, Hainan Vocational University of Science and Technology enrolled 2,500 undergraduates first time, which opened a new process of the rapid development of the university. The first freshmen of Guiyang kangtang Vocational University enrolled only 1,000 undergraduates but quickly completed the admission process within two days. According to these two vocational institutes, the undergraduate, vocational situation is much better in present regions.

According to government statistical data, the enrollment situation of some professional undergraduate colleges in 2021 is not so satisfactory. After the first admission, most vocational institutes did not achieve their target. For instance, At Chongqing Electromechanical Vocational and Technical University, 1795 students were enrolled in 2021, which could not complete the target. There remains a shortage of 931 students. The enrollment plan of Shaanxi Automobile Vocational University is 2000, while enrolled only 1300 students [19]. The development of vocational undergraduate enrollment contradicts the regional school distribution, student source, majors, competitive colleges, and other factors, much more dependent on the parents and student concept to change their educational track into the vocational side. According to the requirements of the Opinions, vocational undergraduate courses will develop steadily, and all provinces and cities will carry out the layout and planning of vocational, undergraduate education [20]. At the same time, there is competition for vocational, undergraduate students, so it is necessary to continue strengthening the professional construction and improving the comprehensive strength of the college to attract high-quality students.

\section{SWOT analysis}

This part of the paper explains the strengths, weaknesses, opportunities, and threats for vocational, local private colleges and universities

\subsection{Strengths of Vocational Education in Private Colleges \\ 5.1.1 Small gap}

There is significantly less but a considerable gap between the application-oriented undergraduate colleges and vocational, undergraduate education. The undergraduate universities will implement an application-oriented education system and pay attention to the training of applied talents with theoretical and practical aspects and cultivate practical skills in the teaching process; professional undergraduate education mainly develops highquality technical talents needed in the production, construction, service, and management. Therefore, if the application-oriented undergraduate college holds vocational, undergraduate education, it can promote the horizontal integration of different types of education, realize the integration of higher vocational undergraduate and application-oriented university courses, and the mutual recognition of credits within the university. It is possible to combine the two or the "double-track" development.

\subsubsection{Existing major degree with the vocational, undergraduate education major}

Most of the current undergraduate majors of local private applied undergraduate courses can be found as the corresponding majors in the Catalogue of Vocational Education Majors 2021. Under the principle of roughly matching majors, applied-oriented undergraduate schools can attract more secondary vocational and vocational high school graduates to apply for local private application-oriented undergraduate courses.[21]

5.1.3 Flexible system and high teamwork efficiency

Since the establishment of local private application-oriented undergraduate colleges was officially approved by 
the Ministry of Education, after years of rapid development, the scale of students has reached a particular scale, and high-quality teachers have been established, with a friendly and stable environment, more capable management team, and complete hardware infrastructure. As a private university, the advantage is concentrating on the strength to do great things, with high efficiency and a flexible mechanism.

\subsection{Weakness for Developing a Vocational Education for Local Private Undergraduate Colleges}

5.2.1 Lack of technical staff

At present, the teachers at private colleges meet the teaching activities of this (specialized) subject. If they undertake vocational, undergraduate education, it is necessary to increase the teaching staff's ability, like introducing other professional, technical talents and social practice elites in the industry.

\subsubsection{Less advantageous majors}

Presently, in preschool education, accounting and art design majors can be enrolled; therefore, local private colleges and universities have fewer characteristics and advantages. If they undertake vocational, undergraduate education, they need to strengthen the construction of attributes and benefits and further upgrade the existing characteristic majors. The characteristics are so important that they sometimes determine vitality.

5.3 Opportunities for Developing Vocational Undergraduate Education in Local Private Undergraduate Colleges 5.3.1 Expansion of enrolment scale

The Opinions pointed out that the enrollment scale of vocational undergraduate education in 2025 should not be less than $10 \%$ of the cation enrollment scale and encourage application-oriented undergraduate schools to carry out vocational, undergraduate education. Under these circumstances, private universities in Inner Mongolia can further expand the enrollment scale and increase the enrollment share, becoming a new growth point for the development of private colleges and universities.

5.3.2 Promote professional upgrading

In the notice of the Ministry of Education on the Catalogue of Vocational Education Majors (2021) (No.2), some new majors have been adjusted, such as the original "financial management" to "Big Data and Financial Management"; "Accounting" to "Big Data" and "Big Accounting", following the development of times and technology, and the construction and application of "big data" in the future teaching activities, the existing majors of private universities can also be upgraded or adjusted.

5.3.3 Advantage of Major expansion

According to the development concept of applied private undergraduate university, universities can enhance the major can be improved in a different field such as "tourism" project, "project system," "senior university" project can establish and develop "smart health pension management." Furthermore, vocational colleges can initiate projects related to social work and party affairs according to social development and actual needs.

5.3.4 Promotion of school-enterprise cooperation and strengthening talent training

Promotion of school-enterprise cooperation, integrating industry and education and combining work and study. Adhere to the pilot principle first and gradually develop, realize the "dual" education mode of integrating industry and education and school-enterprise cooperation. Enterprises should try to participate in the whole process of talent training in vocational colleges, achieve professional joint construction, and cultivate technical and skilled talents that adapt to the new economic development situation. Under the traditional vocational education system, the junior college talents cannot fully meet the needs of technical skill talents for industrial upgrading [22]. Therefore, enterprises will recruit more professional undergraduate graduates with more solid theoretical knowledge and more vital technical innovation ability. The training mode has been upgraded to school-enterprise integration, the teaching staff has been upgraded to expert integration, the serviceability has been upgraded to leading, and the part-time teachers in enterprises has been continuously expanded to form a mixed school-enterprise teacher team.[23]

According to the Notice of the Setting Standards of Undergraduate Vocational Schools (Trial) (No.1), the "proportion of" double teachers " teachers with more than three years of working experience in the enterprise or production and service shall not be less than 50\%. These steps bring the new technology and technology of the enterprise to talent training. Combine theory and practice, teaching and time seamless docking [24].

\subsection{Threats for Developing Vocational Undergraduate Education}

There is enormous competition in public undergraduate institutions. Well-known public colleges in the area are also facing this threat. If vocational, undergraduate education is carried out simultaneously, they will face a highly competitive environment in the hardware facilities and capital investment. In contrast, government support is relatively tiny in finance, funds, projects, and teachers.

\section{Conclusion}

To conclude, the main reason for the private application-oriented undergraduate colleges to flourish in local areas 
is that the talents training programs can meet the market demand. Vocational undergraduate education mainly trains high-quality technical and skilled talents needed in the frontline of production, construction, service, and management. Therefore, the participation of local undergraduate education of applied colleges and universities in vocational education can promote the horizontal integration of different types of education realize the mutual selection and credit recognition of higher vocational, undergraduate courses of applied universities in the university. It is possible to combine the two or "double-track" development.

\section{References:}

1. Sun Jian. A Study on the Values of Applied Undergraduate College Students in the New Media Era [J]. Computer Knowledge and Technology, 2021,17(32):176-177+209.DOI:10.14004/j.cnki.ckt. 2021.3261.

2. Zhang Wanying. Research on the Craftsman Spirit Training Path of Applied Undergraduate Students [J]. Technology wind, 2021(29):190-192.DOI:10.19392/j.cnki.1671-7341.202129063

3. Xu Guoqing, Lu Suju, Kuang Ying, He Yanfang, Su Hang. Connotation, international status and development strategy of vocational undergraduate education [J]. Mechanical Vocational Education, 2020(03):16+24.DOI:10.16309/j.cnki.issn. 1007-1776.2020.03.001.

4. Liang Guosheng. Professional undergraduate course, here is it![N]. China Youth Daily, 2021-10-25 (006). DOI:10.38302/n.cnki.nzgqn. 2021.003809.

5. Li Yuzhu. On the Mass Talent Training in the context of Intangible Cultural Heritage [J]. Vocational and Technical Education, 2015 (4): 78-81.

6. Yuan Shuai. Relying on the university intangible cultural heritage studio to carry out the innovative practice research on the talent training mode of university cultural and creative products [J]. Light Industry Technology, 2018 (7): 81-85.

7. Chen Yanming ". Teaching Reform of Clothing Design under the Vision of Curriculum Ideological and Politics " [J]. Shandong Textile economy, 2020 (3): 36-37.

8. Yu Qiding. Review of the orientation and scale development of vocational education since the establishment of New China [J]. Journal of Zhejiang Normal University (Social Science Edition), 2019,44 (05): 12-21.

9. Zhou Ting. Curriculum Teaching Design and Implementation of Creative Product Design below [J]. Southern Agricultural Machinery, 2020 (2): 101-102.

10. Shi Huajian, Yang Rong. The Protection and inheritance of Yangzhou Folk Culture and Art in the construction of the Grand Canal Cultural Belt [J]. Popular Literature and Art, 2019 (10): 57-58.

11. Yao Yaqian, Xu Jinye, Shen Yu. Promote the protection and inheritance of Yangzhou Intangible Cultural heritage in the form of cultural and creative products [J]. ,2019(4):188-189.

12. Shi Jihua, Wu Yufeng and Li Qiang The advantages and paths of Yangzhou local universities participating in the protection and inheritance of intangible cultural heritage [J]. Journal of Yangzhou Education College, 2019 (4): 74-77.

13. Sun Lu, Kong Jin, Chen Haipeng, et al. Local culture is integrated into higher vocational art talent training, "three rooms and three integration" mode [J]. Journal of Yangzhou Vocational University, 2019 (2): 54-57.

14. Make up and make good use of the new vocational education professional catalogue service "14th Five-Year Plan" high-quality development [J]. Chen Ziqi. Chinese Vocational and Technical Education. 2021(07)

15. Vocational Education Professional Directory evolution, role and implementation [J]. Wang Yannan. Chinese Vocational and Technical Education. 2021(07)

16. View for the construction of professional teachers in vocational education courses. Zhang Botao. Scientific consultation $[\mathrm{J}]$ (Science and technology management). 2016(12)

17. Exploration of the establishment reform of vocational education majors for the disabled [J]. Pan Wei. Journal of Harbin Vocational and Technical College. 2016(03)

18. Research on the Discipline System Construction of Professional Vocational Education [J]. Zhu Jianguo. seek. 2014(11)

19. Setting of Vocational Education in China [J]. Zhou Guangming. The Education and Teaching Forum. 2015(22)

20. Current situation and evaluation of vocational education professional construction and industrial development at home and abroad [J]. Zhao Ying. Changjiang River Cong. 2020(05)

21. Notice of the Ministry of Education on the Issuance of the Catalogue of Vocational Education Majors (2021) [J]. Forum on Education Sciences. 2021(12)

22. Policy recommendations on the development of professional standards in vocational education [J]. Shu Jianhua. The Vocational Education Forum. 2005(30)

23. On the Reality of Vocational Education Professional Setting [J]. Meng Xianping. The Vocational Education Forum. 2003(18)

24. On the Reality of Vocational Education Professional Setting [J]. Meng Xianping. The Vocational Education Forum. 2003(18) 